\title{
STUDI PARAMETER AIR DAN RADIOAKTIVITAS ALAM PERAIRAN SUNGAI SEROPAN GUNUNGKIDUL
}

\author{
Tri Rusmanto, Agus Taftazani \\ PTAPB - BATAN Yogyakarta
}

\begin{abstract}
ABSTRAK
STUDI PARAMETER AIR DAN RADIOAKTIVITAS ALAM SAMPEL AIR, SEDIMEN SUNGAI SEROPAN GUNUNGKIDUL. Kualitas air Sungai Seropan sebagai bahan baku air bersih (rumah tangga) harus dipantau kualitasnya melalui parameter fisik, kimia, biologi dan radioaktivitas. Telah dilakukan studi kualitas air tersebut dengan parameter penelitian suhu, suspended solid (SS), radioaktivitas gross $\beta$ dan $\gamma$, kesadahan, $C O D, B O D$, escherichia coli. Sampel air dan sedimen sungai diambil pada bulan Februari (penghujan) dan Agustus (kemarau) 2006. Didapat hasil pengukuran parameter kualitas air sungai Seropan berturut-turut adalah suhu rata-rata $28^{\circ} \mathrm{C}$; SS maksimum $48 \mathrm{mg} / \mathrm{L}, \mathrm{pH}$ maksimum 6,8; kesadahan maksimum 257,49 mg/L; COD maksimum $8 \mathrm{mg} / \mathrm{L}$, BOD maksimum 4,9 mg/L, bakteri E. colli max $>2400 \mathrm{mpn} / 100 \mathrm{~mL}$, gross $\beta$ air maksimum 0,9071 Bq/L. Semua parameter tersebut masih di bawah kadar maksimum dari Keputusan Gubernur Kepala Daerah Istimewa Yogyakarta No/214/KPTS/1991 dan Keputusan Menteri Kesehatan Republik Indonesia Nomor 907/Menkes/SKNII/2002. Sampel sedimen tidak dapat dibandingkan karena belum tercantum dalam baku mutunya. Hasil identifikasi radionuklida alam pemancar gamma pada sampel air sungai adalah TI208 dan K-40 sedangkan pada sampel sedimen terdeteksi lebih banyak yaitu TI-208, Ac-228, Ra-226, $\mathrm{Pb}-212, \mathrm{~Pb}-214, \mathrm{Bi}-214, \mathrm{Ac}-228, \mathrm{Ac}-228$ dan K-40.
\end{abstract}

Kata kunci: Sungai Seropan, parameter fisis, kimia dan biologis, radioaktivitas $\beta$ dan radionuklida alam.

\section{ABSTRACT}

EVALUATION OF PHYSICALS, CHEMICAL, BIOLOGICALS AND RADIOACTIVITY PARAMETERS OF SEDIMENTS and WATER SAMPLES of SEROPAN RIVER GUNUNGKIDUL. Seropan river water quality as residential water resources can be controlled by physical, chemical, and biological parameters. The water quality with the parameters of temperature, suspended solid (SS), gross $\beta$ radioactivity , hardwater, $C O D, B O D$, Escherichia Coli have been experimentally conducted. The sediment and water samples have been taken at February and August 2006. Measurement result of Seropan river water quality showed that the temperature was $28^{\circ} \mathrm{C}$, maximum SS was $48 \mathrm{mg} / \mathrm{L}$, maximum $\mathrm{pH}$ was 6.8 maximum hard water was $257.49 \mathrm{mg} / \mathrm{L}$, maximum COD was $8 \mathrm{mg} / \mathrm{L}$, maximum BOD was $4.9 \mathrm{mg} / \mathrm{L}$, maximum bacterial E. coli > $2400 \mathrm{mpn} / 100 \mathrm{~mL}$, maximum water gross $\beta$ was $0.9071 \mathrm{~Bq} / \mathrm{L}$. All the parameters were lower than maximum permissible for water condition that decided by Governor of Yogyakarta Special Province No/214/Kpts/1991 and Public Health Minister of Republic of Indonesia Number 907/Menkes/SKVII/2002. Sediment sample can not be evaluated because it was not included yet in the river water quality. Natural radionuclides gamma transmitter identified were TI-208 and K-40 of water sample. Sediment samples have been detected TI-208, Ac-228, Ra-226, Pb-212, Pb-214, Bi-214, Ac-228, Ac-228 and K-40 radionuclides.

Keywords: Seropan River, physical-, chemical- and biological-parameter, radioactivity of $\beta$ and natural radionuclides 


\section{PENDAHULUAN}

Air sungai Seropan akan dipergunakan untuk keperluan air rumah tangga (bahan air bersih), maka harus dipantau melalui beberapa parameter, antara lain parameter fisik, kimia, dan biologi baik pada musim kemarau maupun penghujan.

Kualitas air sungai pada musim kemarau dipengaruhi terutama oleh kualitas sumber air (belik/luweng) yang mengalir ke sungai. Pada musim penghujan, kualitas air sungai dipengaruhi oleh selain kualitas sumber air juga oleh kualitas air hujan yang masuk kesungai, baik yang langsung maupun setelah melewati lahan pertanian/perkebunan, area industri atau pekarangan rumah tangga. yang akhirnya masuk ke sungai Seropan. Diperkirakan kualitas air sungai pada musim penghujan memiliki harga BOD, COD, bakteri E.colli yang lebih tinggi dibandingkan pada musim kemarau.

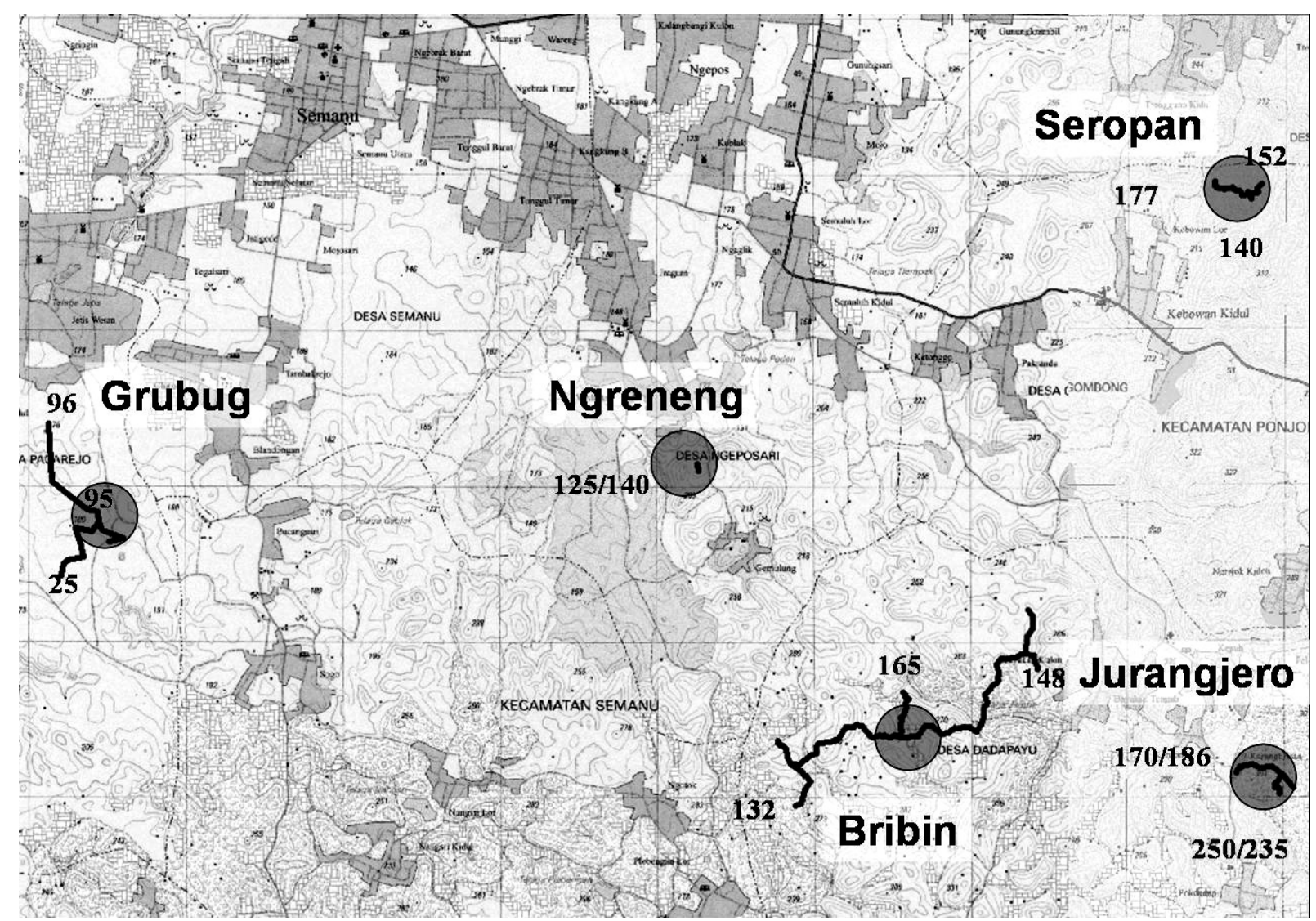

Gambar 1. Peta lokasi Sungai Bawah Tanah Seropan, Semanu, Gunung Kidul

Adapun tujuan penelitian ini antara lain agar dapat dipunyai kualitas air dan sedimen sungai Seropan dengan parameter sifat fisik (suhu, suspended solid, gross $\beta$, jenis radionuklida alam pemancar $\gamma$ ), sifat kimia (kesadahan dan $\mathrm{COD}$ ) dan sifat Biologi $\left(\mathrm{BOD}_{5}\right.$ dan bakteri Escherichia Coli). Pengamatan kualitas air sungai dilakukan secara periodis, selama 2-3 tahun pada musim kemarau dan penghujan yang akan dikumpulkan sebagai data bank. Data hasil pengukuran parameter air tersebut pada sampel air di Sungai Seropan, kemudian dibandingkan dengan SK Gubernur Kepala Daerah Istimewa Yogyakarta No/214/KPTS/1991 mengenai Baku Mutu Air Golongan $B^{[1]}$ dan Keputusan Menkes RI Nomor 907 Tahun 2002. Pengambilan sampel lingkungan dilakukan pada bulan Februari (musim penghujan) dan Agustus (musim kemarau) 2006. Diharapkan data uji kualitas air sungai Seropan ini dapat dipakai sebagai salah satu pertimbangan oleh yang berwenang dalam pemanfaatan air sungai Seropan. 
Studi parameter air dan radioaktivitas alam sampel air, sedimen Sungai Seropan Periode I, Semanu, Gunungkidul

\section{TATA KERJA}

\section{Bahan :}

Sampel air dan sedimen dari sungai Seropan, sumber standar multi gamma ( Eu-152 ) untuk kalibrasi alat, bahan standar sekunder dan primer (SRM).

\section{Alat :}

Penggerus, ayakan 100 mesh, alat gelas, $\mathrm{pH}$ meter, termometer, timbangan, alat cacah gross $\beta$ (dengan Geiger Mueller, GM), unit spektrometer $\gamma$ (dengan detektor $\mathrm{Ge}(\mathrm{Li})$ dan software Maestro II, Ortec) dan peralatan pembantu lainnya.

\section{Cara Kerja:}

Pengambilan sampel air dan sedimen ${ }^{[5]}$ sungai Seropan dilakukan di 3 lokasi, sebagaimana terlihat dalam Tabel 1.

Tabel 1. Pengambilan Sampel pada Bulan Februari 2006 (musim penghujan).

\begin{tabular}{|l|l|c|c|c|}
\hline No & KODE SAMPEL & LOKASI & JENIS SAMPEL & JUMLAH \\
\hline 1 & Air Lokasi I & Air sungai DAM I & Air & $2 \times 5 \mathrm{~L}$ \\
\hline 2 & Air Lokasi II & Air sungai 400 meter dari DAM.I & Air & $2 \times 5 \mathrm{~L}$ \\
\hline 3 & Air Lokasi III & Air sungai DAM II. & Air & $2 \times 5 \mathrm{~L}$ \\
\hline 4 & Sedimen Lokasi I & Sedimen DAM I & Sedimen & $2 \times 2 \mathrm{~kg}$ \\
\hline 5 & Sedimen Lokasi II & Air sungai 400 meter dari DAM.I & Sedimen & $2 \times 2 \mathrm{~kg}$ \\
\hline 6 & Sedimen Lokasi III & Air sungai DAM II. & Sedimen & $2 \times 2 \mathrm{~kg}$ \\
\hline
\end{tabular}

Tabel 2. Pengambilan sampel pada bulan Agustus 2006 (musim kemarau).

\begin{tabular}{|l|l|c|c|c|}
\hline No & KODE SAMPEL & LOKASI & JENIS SAMPEL & JUMLAH \\
\hline \hline 1 & Air Lokasi I & Air sungai DAM I & Air & $2 \times 5 \mathrm{~L}$ \\
\hline 2 & Air Lokasi II & Air sungai 400 meter dari DAM.I & Air & $2 \times 5 \mathrm{~L}$ \\
\hline 3 & Air Lokasi III & Air sungai DAM II. & Air & $2 \times 5 \mathrm{~L}$ \\
\hline 4 & Sedimen Lokasi I & Sedimen DAM I & Sedimen & $2 \times 2 \mathrm{~kg}$ \\
\hline 5 & Sedimen Lokasi II & Air sungai 400 meter dari DAM.I & Sedimen & $2 \times 2 \mathrm{~kg}$ \\
\hline 6 & Sedimen Lokasi III & Air sungai DAM II. & Sedimen & $2 \times 2 \mathrm{~kg}$ \\
\hline
\end{tabular}

Keterangan : a. Suhu dan pH diukur pada saat pengambilan sampel, dimasing-masing lokasi.

b. Preparasi sampel untuk pengukuran gross $\beta$, identifikasi radionuklida pemancar $\gamma$ dilakukan dengan mengacu Agus Taftazani $(2000)^{[2]}$

Metode pengukuran parameter dalam penelitian ini adalah sebagai berikut:

1. Parameter Fisik: - Penentuan warna, dengan metode Visual + Spektrofotometer.

- Penentuan Bau dengan metode Organoleptik.

- Penentuan Suhu, dengan termometer.

- Penentuan padatan tersuspensi dengan metode gravimetri.

- Penentuan radioaktivitas gross $\beta$ dengan alat cacah gross $\beta$ (detektor $G M)^{[3,4,5]}$

-Identifikasi radionuklida alam dengan metode spektrometri y (detektor GeLi). ${ }^{[2,46]}$

2. Parameter Kimia: - Penentuan kesadahan dengan metode titrimetri (EDTA)

- Penentuan COD dengan metode titrimetri.

- Penentuan keasaman $(\mathrm{pH})$ dengan metode potensiometri (pH-meter).

3. Parameter Biologi: - Penentuan bakteri E. Colli dengan metode MPN.

- Penetuan BOD hari kelima, dengan metode titrimetri. 


\section{HASIL PENELITIAN DAN PEMBAHASAN}

Jumlah sampel dan lokasi pengambilan sampel lingkungan perairan Seropan dapat dilihat sebagaimana tercantum dalam Tabel 1 dan 2. Pengambilan sampel dilakukan pada musim penghujan Februari 2006 dan pada musim Kemarau Agustus 2006.

Setelah sampel lingkungan diatas dipreparasi sesuai dengan tujuan analisisnya, kemudian dilakukan pengukuran-pengukuran parameternya. Hasil penentuan parameter fisika, kimia dan biologi pada air sungai Seropan dapat dilihat pada Tabel 3 sampai dengan Tabel 10.

Tabel 3. Hasil pengukuran Parameter air Sungai Seropan.

\begin{tabular}{|c|c|c|c|c|c|c|c|c|c|}
\hline \multirow{3}{*}{ No } & \multirow{3}{*}{ Parameter } & \multicolumn{6}{|c|}{ Sampel air } & \multirow{3}{*}{ Metode } & \multirow{3}{*}{ Baku Mutu } \\
\hline & & \multicolumn{3}{|c|}{ Februari 2006} & \multicolumn{3}{|c|}{\begin{tabular}{|l|} 
Agustus 2006 \\
\end{tabular}} & & \\
\hline & & Lks-1 & Lks-2 & Lks-3 & Lks-1 & Lks-2 & Lks-3 & & \\
\hline 1 & Suhu $\left({ }^{\circ} \mathrm{C}\right)$ Udara/air & $27 / 29$ & $\begin{array}{l}27 / 2 \\
9\end{array}$ & $\begin{array}{l}27 / 2 \\
9\end{array}$ & $\begin{array}{l}28 / 3 \\
0\end{array}$ & $\begin{array}{l}28 / 3 \\
0\end{array}$ & $\begin{array}{l}28 / 3 \\
0\end{array}$ & Thermometri & $\begin{array}{l}\text { Perbedaan suhu udara } \\
\text { dan air, mak. } 3^{\circ} \mathrm{C}\end{array}$ \\
\hline 2 & $\mathrm{pH}$ & 6,8 & 6,8 & 6,8 & 6,0 & 6,0 & 6,0 & Potensiometri & $6,5-8,5$ \\
\hline 3 & $\begin{array}{l}\text { Suspended material } \\
\text { (mg/L) }\end{array}$ & 27 & 30 & 48 & 1 & 1 & 1 & Gravimetri & $500 \mathrm{mg} / \mathrm{l}$ \\
\hline 4 & Bau & - & - & - & - & - & - & Organoleptik & - \\
\hline 5 & Rasa & - & - & - & - & - & - & & - \\
\hline 6. & Kekeruhan (NTU) & 19 & 18 & 36 & 1 & 1 & 1 & & \\
\hline
\end{tabular}

* Surat Keputusan Gubernur Kepala Daerah Istimewa Yogyakarta No/214/KPTS/1991 mengenai Baku Mutu Air Golongan B

Data perbedaan suhu udara dengan air masih $<3^{\circ} \mathrm{C}$. Terlihat data pengamatan suhu, $\mathrm{pH}, \mathrm{SS}$ dan bau pada Tabel 3 baik pada musim kemarau maupun penghujan masih dibawah ambang batas bakumutu menurut Keputusan Gubernur Kepala Daerah Istimewa Yogyakarta No. 214/KPTS/1991 mengenai Baku Mutu ${ }^{(3)}$ Air Golongan B, untuk air rumah tangga/bahan air PAM, berarti air sungai tersebut masih baik dari segi parameter suhu, pH, bau dan rasa.

Dari Tabel 3 terlihat harga SS dan kekeruhan pada musim kemarau < musim penghujan, hal ini disebabkan dengan masuknya air hujan (yang langsung maupun yang telah lewat lahan industri-pertanian-rumah tinggal) dimusim penghujan terjadi pengadukan sungai sehingga menambah kekeruhan air sungai.

Penentuan kesadahan dengan Titrimeteri: Digunakan larutan EDTA 0,01 M sebagai titran, dimana harga dari 1 liter EDTA 0,01 M sesuai dengan $1 \mathrm{mg}$ kesadahan yang dinyatakan sebagai $\mathrm{CaCO}_{3}$.

Perhitungan kesadahan :

$$
\text { Konsentrasi } \mathrm{Ca}^{2+} \text { sebagai } \mathrm{mg} \mathrm{CaCO}_{3} / \mathrm{Lt}=\frac{\mathrm{Ax} 1,0009 \times 1000 \times \mathrm{xf}}{\mathrm{B}}
$$

\section{Dimana :}

A : volume ml titran EDTA yang digunakan.

B : volume $\mathrm{ml}$ sampel (sebelum diencerkan).

1,0009 : ekivalensi antara $1 \mathrm{ml}$ EDTA $0,01 \mathrm{M}$ dan $1 \mathrm{mg}$ kesadahan sebagai $\mathrm{CaCO}_{3}$.

f : faktor perbedaan kadar larutan EDTA menurut standarisasi dengan $\mathrm{CaCO}_{3}(\mathrm{f}<1)$.

Terlihat data pengamatan kesadahan pada Tabel 4 baik pada musim kemarau maupun penghujan masih di bawah ambang batas Bakumutu sesuai dengan Surat Keputusan Gubernur Kepala Daerah Istimewa Yogyakarta No. 214/KPTS/1991 mengenai Baku Mutu Air Golongan B. Sehingga air sungai tersebut masih baik dari segi angka kesadahannya. 
Studi parameter air dan radioaktivitas alam sampel air, sedimen Sungai Seropan Periode I, Semanu, Gunungkidul

Terlihat harga kesadahan pada musim kemarau hampir sama dengan musim penghujan, hal ini menunjukkan adanya air hujan (yang langsung maupun yang telah lewat lahan industri-pertanian-rumah tinggal) tidak mempengaruhi kesadahan air sungai.

Tabel 4. Volume titrasi EDTA dan Angka Kesadahan air sungai Seropan.

\begin{tabular}{|l|c|c|c|c|}
\hline \multirow{2}{*}{ No. } & \multirow{2}{*}{ Sampel Air } & \multicolumn{2}{|c|}{ Kesadahan $\left(\mathrm{CaCO}_{3}\right) \mathrm{mg} / \mathrm{L}$} & \multirow{2}{*}{ Kesadahan Bakumutu* } \\
\cline { 3 - 4 } & & Februari 2006 & Agustus 2006 & \\
\hline \hline 1. & Lokasi I & 245,42 & 257,49 & $500 \mathrm{mg} / \mathrm{L}$ \\
\hline 2. & Lokasi II & 237,37 & 257,49 & $500 \mathrm{mg} / \mathrm{L}$ \\
\hline 3 & Lokasi III & 221,28 & 197,14 & $500 \mathrm{mg} / \mathrm{L}$ \\
\hline
\end{tabular}

Tabel 5. Hasil Pengujian COD air Sungai Seropan.

\begin{tabular}{|l|c|c|c|c|}
\hline \multirow{2}{*}{ No. } & \multirow{2}{*}{ Sampel Air } & \multicolumn{2}{|c|}{ Kesadahan $\left(\mathrm{CaCO}_{3}\right) \mathrm{mg} / \mathrm{L}$} & \multirow{2}{*}{ Kesadahan Bakumutu, mg/L* } \\
\cline { 3 - 4 } & & Februari 2006 & Agustus 2006 & \\
\hline 1. & Lokasi I & 16 & 8 & \multirow{2}{*}{10} \\
\hline 2. & Lokasi II & 8 & 8 & \multirow{2}{*}{10} \\
\hline 3 & Lokasi III & 8 & 8 & \\
\hline
\end{tabular}

* Surat Keputusan Gubernur Kepala Daerah Istimewa Yogyakarta No. 214/KPTS/1991 mengenai Baku Mutu Air Golongan B

Sampel yang diambil pada perairan sungai Bribin pada Bulan Februari 2006 lokasi I memiliki angka COD sebesar $16,0 \mathrm{mg} / \mathrm{L}$ sedangkan sampel dari lokasi II dan III memiliki angka COD sebesar 8,0 mg/L, sedang dimusim kemarau semua berharga $8,0 \mathrm{mg} / \mathrm{L}$. Harga COD 16,0 mg/L mungkin terjadi karena telah terjadi pencemaran pada waktu sampling atau preparasi atau pengukurannya. Sehingga dapat disimpulkan angka ratarata untuk parameter $C O D$ sebesar $8 \mathrm{mg} / \mathrm{L}$ baik pada musim kemarau maupun penghujan di 3 lokasi sampling tersebut dan harga COD tersebut masih dibawah ambang batas yang diperbolehkan (10 mg/L).

Adapun pengukuran BOD nya dapat dilihat dalam tabel 6 :

Tabel 6. Hasil Perhitungan BOD air Sungai Seropan

\begin{tabular}{|l|l|c|c|c|}
\hline \multirow{2}{*}{ No. } & \multirow{2}{*}{ Sampel Air } & \multicolumn{2}{|c|}{ Hasil Uji BOD (mg/L) sampel } & \multirow{2}{*}{ Kesadahan Bakumutu, mg/L* } \\
\cline { 3 - 4 } & & Februari 2006 & Agustus 2006 & \\
\hline \hline 1. & Lokasi I & 4,9 & 1,7 & \multirow{2}{*}{5} \\
\hline 2. & Lokasi II & 2,3 & 1,6 & \multirow{2}{*}{5} \\
\hline 3. & Lokasi III & 2,0 & 1,6 & \\
\hline
\end{tabular}

Harga $B O D$ air sungai pada musim kemarau maupun musim penghujan semuanya masih dibawah batas maksimum yang diperbolehkan, yaitu sebesar $5 \mathrm{mg} / \mathrm{L}$.

Terlihat harga BOD pada musim kemarau < musim penghujan, hal ini disebabkan telah terjadi kontaminasi dari air hujan (yang langsung maupun yang telah lewat lahan industri-pertanian-rumah tingla) sehingga cemaran biologis semakin banyak.

\section{Aspek Bakteriologis}

Jumlah maksimum yang dianjurkan untuk parameter bakteriologis (Esherichia Coli) adalah sebesar 2100 MPN/100 ml, disini terlihat jumlah E.coli pada musim penghujan > musim kemarau, hal ini disebabkan telah terjadi kontaminasi dari air hujan (yang langsung maupun yang telah lewat lahan industri-pertanian-rumah tangga) sehingga bakteri E.Coli nya semakin banyak. Hal ini mendukung data harga BOD (Tabel 5) pada musim penghujan juga lebih besar adari pada musim kemarau.

Tri Rusmanto, dkk.

GANENDRA, Vol. XI, No. 1, Januari 2008 
Studi parameter air dan radioaktivitas alam sampel air, sedimen Sungai Seropan Periode I, Semanu,

Gunungkidul

Tabel 7. Hasil Penentuan Bakteri Escherichia Coli pada sampel air yang diambil dari Sungai Seropan

\begin{tabular}{|l|l|c|c|c|}
\hline \multirow{2}{*}{ No. } & \multirow{2}{*}{ Sampel Air } & \multicolumn{2}{|c|}{ Hasil Uji E-Coli (MPN/100 mL) } & \multirow{2}{*}{ Bakumutu (MPN/100 mL) } \\
\cline { 3 - 4 } & & Februari 2006 & Agustus 2006 & \\
\hline 1. & Lokasi I & $>2400$ & 150 & \multirow{2}{*}{2100} \\
\hline 2 & Lokasi II & $>2400$ & 150 & \multirow{2}{*}{210} \\
\hline 3 & Lokasi III & $>2400$ & 210 & \\
\hline
\end{tabular}

\section{Aspek Radioaktivitas}

Aspek radioaktivitas gross Beta dengan detektor Geiger Mueller (GM) serta identifikasi radionuklida pemancar $\gamma$ dengan detektor $\mathrm{Ge}(\mathrm{Li})$ dan software Maestro II.

\section{Aktivitas Gross Beta $(\beta)$}

Dari hasil analisis dan perhitungan aktivitas gross beta terhadap sampel air sungai dan sedimen dapat dilihat pada Tabel 8.

Tabel 8. Hasil Pengukuran Gross Beta $(\beta)$ pada sampel air dan sedimen sungai

\begin{tabular}{|c|c|c|c|}
\hline \multirow{2}{*}{ No } & \multirow{2}{*}{ Kode Sampel } & \multicolumn{2}{|c|}{ Aktivitas } \\
\hline & & Februari 2006 & Agustus 2006 \\
\hline & & Gross $\beta$ & Gross $\beta$ \\
\hline & SAMPEL AIR (Bq/L) & & \\
\hline 1 & Lokasi I (air) & $0,53 \pm 0,04$ & $0,13 \pm 0,02$ \\
\hline 2 & Lokasi II (air) & $0,58 \pm 0,05$ & $0,14 \pm 0,04$ \\
\hline 3 & Lokasi III (air) & $0,54 \pm 0,05$ & $0,11+0,02$ \\
\hline & SAMPEL SEDIMEN (Bq/gr) & & \\
\hline 4 & Lokasi I (sedimen) & $0,85 \pm 0,04$ & $0,22 \pm 0,01$ \\
\hline 5 & Lokasi II (sedimen) & $0,86+0,05$ & $0,23+0,01$ \\
\hline 6 & Lokasi III (sedimen) & $0,91+0,07$ & $0,23 \pm 0,03$ \\
\hline
\end{tabular}

Data hasil pengukuran radioaktivitas gross $\beta$ dalam Tabel 8 menunjukan bahwa perairan sungai Seropan adalah aman dari segi gross $\beta$, baik untuk sedimen maupun airnya, karena besar radioaktivitas gros $\beta$ disemua titik lokasi masih dibawah batas ambang baku mutu tentang Baku Mutu ${ }^{(3)}$. Badan Air Golongan B batas yang diperbolehkan Gross $\beta=1,00 \mathrm{~Bq} / \mathrm{L}$. Tabel 8 juga menginformasikan bahwa harga gross beta dalam air pada musim penghujan pada umumnya lebih besar adari pada musim kemarau. Adanya penambahan gross beta ini dimungkinkan karena kualitas air hujan sendiri atau tertambahi sewaktu melewati/mengalir pada permukaan tanah (tanaman,industri, rumah tangga). Pada sampel sedimen juga cenderung terjadi sama. Untuk mengetahui jenis radionuklida yang memancarkan beta dan sekaligus gamma, maka perlu dianalisis dengan spektrometer gamma dan hasilnya dapat dilihat sebagaimana dalam berikut ini.

\section{Aktivitas Radionuklida Alam Pemancar Gamma (Y)}

Dari hasil pengukuran dan perhitungan maka didapatkan harga aktivitas radionuklida alam pemancar gamma pada sampel air sungai dan sedimen sungai Seropan disajikan pada Tabel 9 dan 10.

\section{Hasil Pengukuran Aktivitas Radionuklida Alam Pemancar Gamma pada Sampel Air Sungai Seropan.}

Tabel 9 menginformasikan bahwa pada umumnya aktivitas radionuklida dalam air pada musim penghujan (Februari) lebih kecil dari pada musim kemarau hal ini berlawanan pada data radioaktivitas beta dan parameter lainya (SS, kekeruhan, COD, BOD dan E.Colli). 
Studi parameter air dan radioaktivitas alam sampel air, sedimen Sungai Seropan Periode I, Semanu, Gunungkidul

Tabel 9. Radionuklida Alam dalam Air Sungai Bawah Tanah Seropan.

\begin{tabular}{|c|c|c|c|c|}
\hline \multirow{2}{*}{ Kode } & \multirow{2}{*}{ Energi, keV } & \multirow{2}{*}{ Isotop } & \multicolumn{2}{|c|}{ Aktivitas Radionuklida ( Bq/Kg ) } \\
\cline { 4 - 5 } & & & Sampling Februari 2006 & Sampling Agustus 2006 \\
\hline Lokasi I & 583 & TI-208 & 0,9635 & 5,538 \\
& 1460 & $\mathrm{~K}-40$ & 2,7027 & 2,976 \\
\hline Lokasi II & 583 & Tl-208 & 0,6024 & 6,267 \\
& 1460 & $\mathrm{~K}-40$ & 3,5252 & 7,07 \\
\hline Lokasi III & 583 & Tl-208 & 0,8437 & 4,817 \\
& 1460 & $\mathrm{~K}-40$ & 5,251 & 5,425 \\
\hline
\end{tabular}

Identifikasi radionuklida alam pemancar gamma pada sampel sedimen radionuklidanya terdeteksi 8 , lebih banyak dari pada yang terdapat pada sampel air sungai sebagimana ditunjukan dalam Tabel 10. Hal ini dapat disebabkan karena afinitas radionuklida untuk berasosiasi dengan sedimen dan partikel-partikel sedimen lebih tinggi daripada afinitas radionuklida terhadap air.

Tabel 10. Hasil Pengukuran Aktivitas Radionuklida Alam Pemancar Gamma pada Sampel Sedimen

\begin{tabular}{|c|c|c|c|c|}
\hline \multirow{2}{*}{ Kode } & \multirow{2}{*}{ Energi, keV } & \multirow{2}{*}{ Isotop } & \multicolumn{2}{|c|}{ Aktivitas Radionuklida ( Bq/Kg ) } \\
\cline { 4 - 5 } & & & Sampling Februari 2006 & Sampling Agustus 2006 \\
\hline \hline Lokasi I & 1460 & $\mathrm{~K}-40$ & 6,247 & 6,521 \\
& 911 & $\mathrm{Ac}-228$ & 1,613 & 2,322 \\
& 609 & $\mathrm{Bi}-214$ & 2,879 & 4,133 \\
& 583 & $\mathrm{Tl}-208$ & 2,170 & 3,012 \\
& 510 & $\mathrm{Tl}-208$ & 1,927 & 8,882 \\
& 351 & $\mathrm{~Pb}-214$ & 0,769 & 3,596 \\
& 238 & $\mathrm{~Pb}-212$ & 3,890 & 5,703 \\
& 186 & $\mathrm{Ra}-226$ & 0,479 & 3,763 \\
\hline Lokasi II & 1460 & $\mathrm{~K}-40$ & 7,873 & 7,873 \\
& 911 & $\mathrm{Ac}-228$ & 0,890 & 3,935 \\
& 609 & $\mathrm{Bi}-214$ & 1,254 & 5,514 \\
& 583 & $\mathrm{Tl}-208$ & 1,562 & 5,304 \\
& 510 & $\mathrm{Tl}-208$ & 1,387 & 7,170 \\
& 351 & $\mathrm{~Pb}-214$ & 1,383 & 4,609 \\
& 238 & $\mathrm{~Pb}-212$ & 0,392 & 3,341 \\
& 186 & $\mathrm{Ra}-226$ & 0,438 & 3,586 \\
\hline Lokasi III & 1460 & $\mathrm{~K}-40$ & 8,421 & 8,695 \\
& 911 & $\mathrm{Ac}-228$ & 1,070 & 5,187 \\
& 609 & $\mathrm{Bi}-214$ & 0,875 & 10,050 \\
& 583 & $\mathrm{Tl}-208$ & 1,197 & 7,595 \\
& 510 & $\mathrm{TI}-208$ & 1,172 & 5,990 \\
& 351 & $\mathrm{~Pb}-214$ & 0,996 & 4,991 \\
& 238 & $\mathrm{~Pb}-212$ & 0,786 & 2,506 \\
& 186 & $\mathrm{Ra}-226$ & 0,306 & 3,763 \\
\hline
\end{tabular}

Ditunjukkan dalam Tabel 10, pada umumnya aktivitas semua radionuklida pada musim penghujan lebih kecil dari pada musim kemarau, hal ini sama dengan data kualitas airny (Tabel 9) dan berlawanan pada data radioaktifitas beta serta parameter lainya, kecuali nuklida K-40 harganya hampir sama untuk semua lokasi sampling. 


\section{KESIMPULAN}

Berdasarkan hasil-hasil pengukuran parameter fisika, kimia, dan biologi pada sampel air sungai Seropan pada sampling Februari (penghujan) dan Agustus (kemarau) 2006, dapat disimpulkan sebagai berikut :

1. Kualitas air sungai Seropan dari segi parameter penelitian diatas, pada musim penghujan lebih jelek dari pada musim kemarau, berarti pengolahan air sungai untuk air baku PDAM pada musim penghujan harus diolah lebih berat dari pada musim kemarau.

2. Kualitas air: harga $\mathrm{pH}$, suhu air, padatan tersuspensi, kesadahan, $\mathrm{COD}, \mathrm{BOD}$, bakteri E.colli, radioaktivitas beta dimusim kemarau dan penghujan masih dibawah batas ambang dari Baku Mutu air Golongan B, SK Gupernur DIY: No.214/KPTS/1991, kecuali bakteri E.colli di musim penghujan. Air sungai Seropan dapat digunakan sebagai bahan baku air rumah tangga jika telah diproses jumlah bakteri Escherichia.colli nya dapat turun sampai dibawah batas ambang Baku Mutu tsb.

3. Radioaktivitas $\beta$ pada sampel sedimen belum tercantum dalam baku mutu perairan sehingga hasil pengukuran untuk sampel sedimen tidak dapat dibandingkan.

4. Hasil identifikasi radionuklida alam pemancar gamma pada sampel air sungai terdeteksi dua jenis radionuklida yaitu TI-208 $(583 \mathrm{KeV})$ dan K-40 $(1460 \mathrm{KeV})$. Untuk sampel sedimen ada delapan jenis radionuklida yang terdeteksi yaitu TI-208 (75 KeV), Ac-228 (93 KeV), Ra-226 (186 KeV), Pb-212 (238 KeV), $\mathrm{Pb}-214$ (295 KeV), Bi-214 (608 Kev), K-40 (1460 KeV).

\section{DAFTAR PUSTAKA}

1. ANONIM., Keputusan Gubernur Kepala Daerah Istimewa Yogyakarta, Pemerintah Prop DIY, Yogyakarta, (1991)

2. AGUS TAFTAZANI, dkk, "Pola Penyebaran Radioaktivitas $\alpha, \beta$ dan Kandungan Radionuklida dalam Cuplikan Kerang Hijau ( Mytilus Viridis L), Sedimen dan Air Laut di Pantai Cirebon dan Pantai Losari Jawa Barat", Prosiding Pertemuan dan Presentasi IImiah Penelitian Dasar IImu Pengetahuan dan Teknologi Nuklir P3TMBATAN, Yogyakarta, (2000)

3. NAREH dan SUTARMAN,, Metode Pengukuran Aktivitas Tingkat Rendah, PSPKR BATAN, Jakarta (1993).

4. AGUS TAFTAZANI, dkk., "Sebaran Radioaktivitas, Radionuklida Alam dan Faktor Akumulasinya Dalam Air, Sedimen dan Tanaman di Perairan Sungai dan Laut Surabaya", Prosiding Pertemuan dan Presentasi IImiah Penelitian Dasar IImu Pengetahuan dan Teknologi Nuklir P3TM- BATAN, Yogyakarta, (2002).

5. SURATMAN., Pengukuran Radioaktivitas Beta, Pusat Penelitian Nuklir Yogyakarta, BATAN, Yogyakarta, (1997).

6. ERDTMANN,G and SOYKA, W., Gamma ray of the Radionuclides Tables for Applied Gamma Ray Spectrometry, Ney York, Wienhein, (1979).

7. HARIJOTO DAN WIDJOWATI., Metode Pengambilan Contoh Air dan Pemeriksaan Bakteriologi Air, Laboratorium Kesehatan Teknik, Yogyakarta, (1977). 